\title{
List of Puppetry Exhibitions by Czech Organisers in the Czech Republic and Abroad 1989-2015
}

\section{Introduction}

Czech puppetry, within professional Czech theatre, is a phenomenon of global importance that can be, without exaggeration, taken as the golden legacy of Czech culture. Given the means of expression of puppet theatre, the puppet does not have to be perceived only as a part of a theatre production, but also as a visual artefact that becomes the object of scholarly historical research, collectors' interest (sometimes turned into a life-long passion) as well as a lucrative commercial item. ${ }^{1}$ This aspect is often one of the few options (in particular for the pre-photographic and pre-video documentary era) in which the testimony of the fleeting artefact of puppet theatre can be preserved.

The historic forms of puppetry culture can be understood mainly thanks to the leading puppet collections in the Czech Republic, curated by the Theatre Department of the National Museum (NM) in Prague, the Theatre History Department of the Moravian Museum (MZM) in Brno, the Chrudim Puppet Museum (MLK) in Chrudim, and other smaller collections in regional museums. Thanks to these and the specialist explications that surround their curating, the history of Czech puppet theatre can be revived in individual thematic exhibitions.

1 The puppet as part of mainstream culture has recently entered the global sphere as a toy or a decorative object on the market with artefacts. After 1989, these became typical souvenir items on offer in the sphere of the Czech and mainly Prague tourist industry, see Martina Černá and Nina Malíkovás essay ‘Česká loutka: Komerční pop, osud nebo národní dědictví?' [The Czech Puppet: Commercial Pop, Fate, or National Heritage?] in Martin Cikánek and Roman Martinec (eds.). Naše národní identita v reflexi uměleckých oborů a kreativních oblastí [Our National Identity as Reflected by the Arts and Creative Disciplines]. Praha: Institut umění - Divadelní ústav, 2013: $270-81$. 
Of great significance also are the collections of individual puppet theatres - be they independent companies or the unique feature of Czech culture, that is institutional puppet theatres as subjects established by individual cities (of which there are currently ten in the Czech Republic). Amongst the municipal puppet theatres, most collections and exhibition activities centre around the Naivní divadlo (Naïve Theatre Liberec), DRAK Theatre of Hradec Králové, with their dedicated exhibition of puppets entitled Labyrint Divadla DRAK (The Labyrinth of the DRAK Theatre), the Brno-based Radost Theatre with its own Puppet Museum (Muzeum loutek), or the Divadlo rozmanitostí of Most (Most Variety Theatre). Amongst the independent ensembles, the most significant is the Divadlo bratři Formanu (The Forman Brothers' Theatre).

Given that puppets and the scenography of past productions often have to be cleared out of the storage space of theatres to make room to new artefacts, fragments of the original wholes tend to be scattered in museums and private collections of visual artists, theatre makers, and puppet theatre lovers; reconstructing their original form is often a difficult task. Partly historical research is facilitated by the documentation of post-1945 theatre curated by the Arts and Theatre Institute in Prague (Institut umění - Divadelní ustav) and made available as online databases offering a variety of information on individual productions (not only basic data but also production photographs, scenographic documentation, audio and video recordings).

Unique collections are also in private hands, among them most importantly those of Jiř́ Vorel, of Marie and Pavel Jirásek, of Milan Knížák and of the Cultural System Via Praga / National Marionette Theatre (Národní divadlo marionet). These artefacts can be seen in partial exhibition projects or in permanent exhibitions, such as in the Marionette Museum in the former St. Jošt Church in Český Krumlov (part of the National Marionette Museum's collection) or the Puppet Museum in Štramberk (part of Milan Knížák’s collection).

The exhibition list below offers a selection of the most significant initiatives around Czech puppets from the social and political changes of November 1989 to date. The list covers only a fraction of the exhibition activities of the Czech National Museum and the Moravian Museum; their collections comprise not only puppets but also Czech theatre history in general. Their exhibitions are mainly focusing on historic Czech puppetry. The Chrudim Puppet Museum is represented here with a selection of the larger exhibitions of their collections, i.e. their international projects and exhibitions dedicated to anniversaries of leading Czech puppet theatre companies or historical eras of Czech puppet theatre. ${ }^{2}$ Occasionally the Chrudim Puppet Theatre presents artefacts in their collections that are of other provenances, not only from Czech theatre culture. The exhibitions organised by the Arts and Theatre Institute, whose collections focus on the theatre cos-

2 The museum continually realises exhibition projects in its spaces, focusing on individual personalities and themes of puppet theatre. An exhaustive list of all these activities since 1989 would disproportionately overwhelm this list. For more details see the MLK webpage at: http:// www.puppets.cz. 
tumes, scenography and puppets, are relatively recent and specialise in the presentation of predominantly contemporary Czech theatre abroad, by means of loans of artefacts from private collections and from puppet theatre companies. In undertaking this task, the Arts and Theatre Institute mediates the work of institutionalised and independent puppet ensembles that undertake no exhibitions, but whose work forms a seminal part of the history and the present of Czech theatre. The final section of the list I provide here is dedicated to exhibitions realised by private collectors and two significant platforms of Czech puppet theatre - the Materinka biennale for preschool children, organised by the Naïve Theatre Liberec, and Skupa's Pilsen Festival (Skupova Plzeň), organised by the Alfa Theatre.

The list below is based on information provided by individual organisers and on the databases of the Arts and Theatre Institute. As the missing data suggest (such as the unknown names of curators or the extent and exact venue of the exhibitions), the documentation archives differ considerably in the levels of detail. This list does not claim to be complete and thorough. Nevertheless, it should serve as a starting point for further research in the history of Czech puppet theatre. The fragmentary nature of the sources used to collate the list is also predicated by the era in question that was characterised by a transition from central control towards the opening of borders and a free democratic society - as can be seen in the increasing extent of international collaboration. Nevertheless, the list is testimony of the overwhelming activities and commitment of the curators of these puppet collections; they offer an unprecedented diversity of individual exhibitions - in their sizes (some of them comprising over five hundred items); in their thematic scopes, from general theatre history to socio-historical contextualisations; in their geographical expansion - spanning not only Bohemia and Moravia but also Central and Western Europe (with surprisingly little in South-Eastern and Southern Europe) and distant venues in America or in Asia. This confirms the premise of the undiminished global significance of the Czech puppet culture that lies behind this list.

\section{Abbreviations}

ATI Institut umění - Divadelní ústav, Praha (Arts and Theatre Institute, Prague)

MLK Muzeum loutkářských kultur, Chrudim (Chrudim Puppet Museum)

MZM Moravské zemské muzeum (Moravian Museum, Brno)

NM Národní muzeum Praha (Czech National Museum, Prague) 
Martina Pecková Černá

List of Puppetry Exhibitions by Czech Organisers in the Czech Republic and Abroad 1989-2015

\section{Czech National Museum (NM), Theatre Department, Prague}

\section{Chapters from the History of Czech Puppet Theatre}

$\begin{array}{ll}\text { Dates } & 1992 \\ \text { Venue } & \text { Petöfi Museum, Budapest, Hungary } \\ \text { Curator } & \text { Jindřiška Patková } \\ \text { Organiser } & \text { NM }\end{array}$

Marionnettes du Musée national de Prague

$\begin{array}{ll}\text { Dates } & 5.9 .1996-2.2 .1997 \\ \text { Venue } & \text { Fondation Neumann, Gingins, Switzerland } \\ \text { Curator } & \text { Jindřiška Patková - Jan Michálek } \\ \text { Organiser } & \text { NM } \\ \text { Co-Organiser } & \text { Fondation Neumann } \\ \text { Note } & \text { An exhibition of ca.250 items: puppets, stage sets, curtains. }\end{array}$

\begin{tabular}{ll} 
České loutky (Czech Puppets) \\
\hline Dates & 18.3.1997-15.8.1997 \\
Venue & NM, Praha, Czech Republic \\
Organiser & NM
\end{tabular}

\section{Czech Historical Puppets}

Dates 20.10.1997-31.12.1997

Venue Städtisches Puppentheater, Magdeburg, Germany

Curator Jindřřška Patková - Jan Michálek

Organiser NM

Co-Organiser Städtisches Puppentheater

Note An exhibition of ca.250 items: puppets, stage sets, curtains.

\section{Tsjechische historische poppen}

Dates $\quad$ 18.6.1998-17.10.1998

Venue Stadhuis Dordrecht, Haag, Netherlands

Curator Jindřriška Patková - Jan Michálek

Organiser NM

Co-Organiser Czech Centre Haag

Note An exhibition of ca.250 items: puppets, stage sets, curtains. 


\section{Loutkový kabaret Freda Schneckenburgera (Fred Schneckenburger's Puppet Cabaret)}

Dates 15.3.1999-25.4.1999

Venue NM, Praha, Czech Republic

Curator Hana Ribi - Jindřiška Patková

Organiser NM

Co-Organiser Museum Bellerive Zürich

The Řiše loutek Theatre - The Place Where UNIMA Was Born

Dates 25.6.2000-25.8.2000

Venue Literraturhaus, Magdeburg, Germany

Curator Jan Kostroun

Organiser NM, Ríše loutek Theatre

Co-Organiser World Congress of the UNIMA, $18^{\text {th }}$ World Puppet Theatre Festival, Magdeburg Note An exhibition of $c a .100$ items: puppets, stage designs, and costumes

\section{Traditional Czech Puppets}

Dates $\quad 6.11 .2007-31.1 .2008$

Venue National Taiwan Museum, Taipei, Taiwan

Curator Lenka Šaldová

Organiser NM

Co-Organiser National Taiwan Museum

Note An exhibition of ca.100 items (puppets, stage sets, curtains), offering an insight into the history of Czech puppet theatre: the phenomenon of folk puppetry and family toy theatres, information on the Czech lands and culture in a broader sense.

Poslové magie - africké loutky a masky

(The Messengers of Magic: African Puppets and Masks)

Dates 27.3.2008-24.8.2008

Venue Náprstek Museum, Praha, Czech Republic

Organiser NM

Note Puppet theatre as part of an African maturity rite. The exhibition was accompanied with tactile items.

\section{Zašlé časy života v maringotkách (Bygone Days of Life in the Circus Caravan)}

Dates 27.3.2008-24.8.2008

Venue $\quad$ Muzeum české loutky a cirkusu (The Museum of Czech Puppets and Circuses), Prachatice, Czech Republic

Curator Hanuš Jordan

Organiser NM 
Martina Pecková Černá

List of Puppetry Exhibitions by Czech Organisers in the Czech Republic and Abroad 1989-2015

Loutkářská šatna Anny Brichové (Anna Brichová's Puppetry Dressing Room)

Dates 28.6.2012-21.10.2012

Venue Muzeum české loutky a cirkusu (The Museum of Czech Puppets and Circuses), Prachatice, Czech Republic

Organiser NM

Co-Organiser Ř́še loutek Theatre

Note Puppet costumes for the legendary Prague-based Říše loutek Theatre, designed and made by the theatre's co-founder, the writer and scenographer Anna Suchardová-Brichová.

\section{Moravian Museum (MZM), Theatre History Department, Brno}

\section{From the Carriage of the Marionettist}

Dates

6.10.1992-31.1.1993

Venue

Theater Brett, Vienna, Austria

Curator

Jiřina Telcová - Jaroslav Blecha - František Pavlíček

Organiser

MZM

Note

104 items. The exhibition presented the phenomenon of Czech travelling puppet theatre on selected artefacts and objects from the MZM collections, namely from the puppet collections of the leading Moravian marionettist families, the Berousek, the Kopecký, the Flachs and the Šimek.

Dynastie Kopeckých aneb Moravské dědictví (The Kopecký Dynasty, or the Moravian Heritage)

\section{Dates 1.9.1993-January 1994}

Venue Letohrádek Mitrovských (Mitrovských Summer Pavilion), Brno, Czech Republic

Curator Jaroslav Blecha

Organiser MZM

Co-Organiser Muzeum města Brna (Brno City Museum)

Note $\quad 75$ items. The exhibition presented artefacts from the collections of the Theatre History Department of MZM, the extant puppets and accessories of the Moravian branches of the Kopecký dynasty - Karel and Václav Kopecký and their father, Karel Kopecký Sr.

\section{Loutky (Puppets)}

Dates

11.12.1994-26.2.1995

Venue

Okresní muzeum Brno-venkov (Regional Museum of the Greater Brno),

Předkláštěří, Czech Republic

Curator Jaroslav Blecha - Alena Kř́žzová

Organiser MZM

Co-Organiser Regional Museum of the Greater Brno, Radost Puppet Theatre

Note $\quad 90$ items. The exhibition presented the general issues of puppet theatre (historical development, individual puppet types, different techniques of manipulation...) through authentic documents. On exhibit were historic puppets from the MZM collections. Contemporary theatre was presented on key productions of the Radost Puppet Theatre in Brno. 


\section{Divadlo českých potulných loutkářù (The Czech Strolling Marionettists' Theatre)}

$\begin{array}{ll}\text { Dates } & 1.5 .1996-20.10 .1996 \\ \text { Venue } & \text { Muzeum Vyškovska (The Vyškov Museum), Dědice, Czech Republic } \\ \text { Curator } & \text { Jaroslav Blecha } \\ \text { Organiser } & \text { MZM }\end{array}$

Note $\quad 96$ items. The exhibition covered Czech puppetry of the late $18^{\text {th }}$ and the $19^{\text {th }}$ centuries, both as popular entertainment and almost the only Czech professional theatre genre known to the people in the country. On exhibit were traditional marionettes, the system of scenography, the repertoire and the life style of the Czech puppeteers.

\section{Lesk a bída pimprlat (The Splendour and the Misery of Puppets)}

$\begin{array}{ll}\text { Dates } & \text { 25.6.1996-15.9.1996 } \\ \text { Venue } & \text { Muzeum města Brna (Brno City Museum), Brno, Czech Republic } \\ \text { Curator } & \text { Jaroslav Blecha } \\ \text { Organiser } & \text { MZM }\end{array}$

Note $\quad 113$ items. The exhibition presented the new acquisitions of the Theatre History Department of MZM, showing puppets and other artefacts, generally in the state in which they had been found, devoid of their former lustre due to long years of disuse. An issue addressed was the problem of acquiring cultural assets for public collections, their preservation and protection.

\section{Dům plný loutek (A House Full of Puppets)}

$\begin{array}{ll}\text { Dates } & \begin{array}{l}28.11 .1996-16.2 .1997 \\ \text { Venue }\end{array} \\ \begin{array}{l}\text { Curator } \\ \text { Organiser šlechtičen (Palace of Noble Ladies), Brno, Czech Republic }\end{array} & \begin{array}{l}\text { Jaroslav Blecha - Pavel Jirásek - Mojmír Brhel - Zdena Poláková } \\ \text { Note }\end{array} \\ & \begin{array}{l}770 \text { items. A joint programme of the Theatre History Department and the Children’s Museum } \\ \text { of MZM. The individual components were the exhibits 'On Czech Family Puppet Theatre' the } \\ \text { long-running workshop 'The Kingdom of Puppets or the Panopticon of Puppets with a Pup- } \\ \text { petry Kitchen', and occasional puppet performances for the public. }\end{array}\end{array}$

\section{Divadlo českých potulných loutkářů (Theatre of Czech Itinerant Puppeteers)}

$\begin{array}{ll}\text { Dates } & \text { 19.7.1998-6.9.1998 } \\ \text { Venue } & \text { Muzeum a Pojizerská galerie (The Jizera Regional Museum and Gallery), } \\ & \text { Semily, Czech Republic } \\ \text { Organiser } & \text { MZM } \\ \text { Note } & 19^{\text {th }} \text { - and early } 20^{\text {th }} \text {-century puppets from the collections of the Theatre History Department of } \\ & \text { MZM. }\end{array}$


Martina Pecková Černá

List of Puppetry Exhibitions by Czech Organisers in the Czech Republic and Abroad 1989-2015

Hračky a divadelní loutky a Afriky, Ameriky a Asie

(The Toys and Theatre Puppets of Africa, America and Asia)

Dates 15.10.1998-5.4.1999

Venue Slovácké muzeum (Slovakian Museum), Uherské Hradiště, Czech Republic

Organiser MZM

Co-Organiser Náprstek Museum

Note Artefacts from the collections of both the organising institutions.

\section{Czech Travelling Puppet Theatre}

Dates $\quad 1.4 .2000-1.11 .2000$

Venue Skjern-Egvad Museum, Skjern, Denmark

Curator Jaroslav Blecha

Organiser MZM

Note $\quad 120$ items. The exhibition presented the Danish public with the Czech traditional travelling marionette theatre on selected authentic documents, artefacts and annotations from the MZM collections.

\section{Loutkové divadlo a jeho podoby (Puppet Theatre and its Forms)}

Dates 31.8.2000-8.10.2000

Venue Galerie Synagoga, Velké Meziříčí, Czech Republic

Curator Irena Tronečková

Organiser MZM

Co-Organiser Muzeum silnic a dálnic ČR (Czech Museum of Roads and Motorways)

Note Marionettes and hand-held puppets of the turn of the century from the MZM collections and local collections, with the replicas of puppets and puppet theatres.

\section{Family Puppet Theatre from Bohemia and Moravia}

$\begin{array}{ll}\text { Dates } & 23.10 .2001-29.10 .2001 \\ \text { Venue } & \text { Galerieraum Stadtsaal, Mistelbach, Germany } \\ \text { Curator } & \text { Jaroslav Blecha } \\ \text { Organiser } & \text { MZM } \\ \text { Co-Organiser } & \text { 23. Internationale Puppentheatertage }\end{array}$

Note $\quad 85$ items. The exhibition presented the phenomenon of the family toy theatre (ca.1900-1950) on authentic artefacts, showing the produce of the leading Czech factories and makers. Artefacts were from the collections of the Theatre History Department of MZM. 


\section{Divadlo s loutkami (Theatre of Puppets)}

$\begin{array}{ll}\text { Dates } & \text { 13.11.2001-20.1.2002 } \\ \text { Venue } & \text { Mramorové sály, Biskupský dvůr (Marble Halls, Bishop’s Courtyard), } \\ & \text { Brno, Czech Republic } \\ \text { Curator } & \begin{array}{l}\text { Jaroslav Blecha } \\ \text { Organiser }\end{array} \\ \text { Mote } & \begin{array}{l}\text { MZM } \\ \text { way, emphasising the contribution of Czech visual artists of the early } 20^{\text {th }} \text { century in the pro- } \\ \text { duction of puppets and table-top toy theatres for the general public. }\end{array}\end{array}$

\section{Česká loutka (The Czech Puppet)}

Dates 25.10.2002-23.2.2003

Venue Císařská konírna Pražského hradu (Emperor’s Stables of the Prague Castle), Praha, Czech Republic

Curator Jaroslav Blecha - Pavel Jirásek

Organiser MZM

Co-Organiser Správa Pražského hradu

Note $\quad 350$ items. The exhibition presented the unique Czech tradition of puppetry from the end of the $18^{\text {th }}$ century to the present on authentic artefacts with a special emphasis on the visual aspect of Czech puppets. The authors programmatically focused on puppets as artefacts with an emphasis on their visual artistic qualities; these were intentionally removed from their theatre context in order to highlight their visual value.

\section{České loutkové divadle rodinné (Czech Family Puppet Theatre)}

\section{Dates 23.6.2003-27.6.2003}

Venue Galerie Divadla Karla Pippicha (Karel Pippich Theatre Gallery), Chrudim, Czech Republic

Curator Jaroslav Blecha

Organiser MZM

Co-Organiser Chrudimská beseda

Note $\quad 85$ items. The exhibition presented the phenomenon of the family toy theatre (ca.1900-1950) on authentic artefacts, showing the produce of the leading Czech factories and makers; artefacts were from the collections of the Theatre History Department of MZM.

\section{Česká loutka (The Czech Puppet)}

Dates 16.12.2003-14.3.2004

Venue Pražákův palác (The Pražák Palace), Brno, Czech Republic

Curator Jaroslav Blecha - Pavel Jirásek

Organiser MZM

Co-Organiser Moravská galerie Brno

Note $\quad 310$ items. Puppets from the beginnings of Czech puppetry till the present. 
Martina Pecková Černá

List of Puppetry Exhibitions by Czech Organisers in the Czech Republic and Abroad 1989-2015

\title{
Czech Family Puppet Theatre
}

Dates 17.5.2004-12.9.2004

Venue Skjern-Egvad Museum, Skjern, Denmark

Curator Jaroslav Blecha

Organiser MZM

Note $\quad 104$ items. The exhibition presented the phenomenon of the family puppet theatre of the early $20^{\text {th }}$ century on authentic artefacts from MZM's collections - industrially produced table-top puppet theatres, puppets, printed stage decorations, properties, puppetry literature and others.

\section{O českém loutkovém divadle rodinném (Czech Family Puppet Theatre)}

\author{
Dates 21.10.2004-31.12.2004 \\ Venue $\quad$ Muzeum Vysočiny (The Vysočina Highlands Museum), Třebíč, Czech Republic \\ Curator Jaroslav Blecha \\ Organiser MZM \\ Co-Organiser Muzeum Vysočiny
}

Note $\quad 85$ items. A smaller exhibition that presented the most important table-top puppet theatres and their puppets from the industrial produce held in the MZM's collections.

\section{O českém loutkovém divadle rodinném (Czech Family Puppet Theatre)}

\author{
Dates 16.6.2005-11.9.2005 \\ Venue Severočeské muzeum (North Bohemian Museum), Liberec, Czech Republic \\ Curator Jaroslav Blecha \\ Organiser MZM \\ Co-Organiser Naivní divadlo Liberec \\ Note $\quad 85$ items. A variant of the smaller exhibition that presented the most important table-top pup- \\ pet theatres and their puppets from the industrial produce held in the MZM's collections.
}

\section{Okno do českého loutkářství (Window to Czech Puppetry)}

\author{
Dates 21.7.2007-16.9.2007 \\ Venue $\quad$ Oblastní galerie Liberec (Regional Gallery Liberec), Liberec, Czech Republic \\ Curator Jaroslav Blecha \\ Organiser MZM \\ Co-Organiser Festival Mateřinka, Naivní divadlo Liberec
}

Note $\quad 540$ items. The preview variant of the project for the Spanish exhibition in Tolosa, presenting the multifarious forms of Czech puppetry. The exhibition displayed authentic artefacts documenting the unique tradition of Czech puppet theatre from the end of the $18^{\text {th }}$ century to the present and the key trends in the development - folk marionettists' theatre, family toy theatres, social puppet theatre with the distinctive contribution of visual artists of Czech Modernism and the work of the institutionalised puppet theatres. The artefacts, mostly unique, came from several Czech public collections and from the inventories of puppet theatres. 


\begin{abstract}
Window to Czech Puppetry
Dates 24.11.2007-3.12.2007

Venue Aranburu Palace, Tolosa, Spain

Curator Jaroslav Blecha

Organiser MZM

Co-Organiser Tolosako Ekinbide Etxea, Centro de Iniciativas, Festival “Titirijai 07”

Note $\quad 540$ items. A part of a large project during the International Puppetry Festival Titirijai 07 in Tolosa, Spain, presenting multifarious forms of Czech puppetry. The exhibition displayed authentic artefacts documenting the unique tradition of Czech puppet theatre from the end of the $18^{\text {th }}$ century to the present and the key trends in the development - folk marionettists' theatre, family toy theatres, social puppet theatre with the distinctive contribution of visual artists of Czech Modernism and the work of the institutionalised puppet theatres. The artefacts, mostly unique, came from several Czech public collections and from the inventories of puppet theatres.
\end{abstract}

\title{
Okno do českého loutkářství (Window to Czech Puppetry)
}

\author{
Dates 20.12.2007-22.3.2008 \\ Venue Palác šlechtičen - Dětské muzeum (Palace of Noble Ladies - Children’s Museum), \\ Brno, Czech Republic \\ Curator Jaroslav Blecha \\ Organiser MZM
}

Note $\quad 540$ items. The preview variant of the project for the Spanish exhibition in Tolosa, presenting the multifarious forms of Czech puppetry. The exhibition displayed authentic artefacts documenting the unique tradition of Czech puppet theatre from the end of the $18^{\text {th }}$ century to the present and the key trends in the development - folk marionettists' theatre, family toy theatres, social puppet theatre with the distinctive contribution of visual artists of Czech Modernism and the work of the institutionalised puppet theatres. The artefacts, mostly unique, came from several Czech public collections and from the inventories of puppet theatres.

\section{Africké loutky - oživlí duchové Afriky (African Puppets - Revived Spirits of Africa)}

\section{Dates}

14.11.2008-8.3.2009

Venue

MZM (pavilion Anthropos), Brno, Czech Republic

Organiser MZM

Note

Puppets loaned from the Polish Czescyn and from the Czech National Museum's Náprstek Museum of Asian, African and American cultures, accompanied by Milan Šarapatka's photographs. 
Martina Pecková Černá

List of Puppetry Exhibitions by Czech Organisers in the Czech Republic and Abroad 1989-2015

\title{
Zapomenuté loutky (Forgotten Puppets)
}

Dates $\quad 4.12 .2009-25.4 .2010$

Venue Galerie Prostor R2, Brno, Czech Republic

Curator Jaroslav Blecha

Organiser MZM

Co-Organiser Brněnské kulturní centrum (Brno Cultural Centre)

Note $\quad 407$ items. The exhibition presented a variety of puppets from the extensive collections of the Theatre History Department of MZM; these artefacts were shown for the first time or after a long period. Besides the exclusive marionettes of the travelling puppet theatre, the exhibition comprised original and serially produced puppets of the social amateur theatre companies, the puppets of the family toy theatres and the technologically, visually and semantically unique puppets of both these eras of Czech puppetry, from its beginnings to the 1950s.

\section{Puppets on the Strings}

$\begin{array}{ll}\text { Dates } & \text { 4.6.2010-5.9.2010 } \\ \text { Venue } & \text { Ringkøbing-Skjern Museum, Ringkøbing, Denmark } \\ \text { Curator } & \text { Jaroslav Blecha } \\ \text { Organiser } & \text { MZM } \\ \text { Co-Organiser } & \text { Ringkøbing-Skjern museum }\end{array}$

Note $\quad 247$ items. The exhibition presented the history of Czech puppet theatre and its key stages of development: the travelling theatre of folk marionettists, the amateur puppet theatre and also partly the work of institutionalised puppetry theatre. The authentic artefacts and documents came from the MZM's collections.

\section{Rodinná loutková divadélka - Skromné stánky múz \\ (Family Marionette Stages: The Humble Temples of the Muses)}

\author{
Dates $\quad 8.12 .2010-30.10 .2011$ \\ Venue Dietrichsteinský palác (Dietrichstein Palace), Brno, Czech Republic \\ Curator Jaroslav Blecha \\ Organiser MZM
}

Note

117 items. The exhibition presented the phenomenon of the family puppet theatre of the early $20^{\text {th }}$ century on authentic artefacts from MZM's collections - a selection of the most attractive and visually valuable artefacts, such as industrially produced table-top puppet theatres, puppets, printed stage decorations, properties. 


\section{Půvaby loutek a soch (Charms of Puppets and Statues)}

$\begin{array}{ll}\text { Dates } & \text { 17.4.2012-7.10.2012 } \\ \text { Venue } & \text { Dietrichsteinský palác (Dietrichstein Palace), Brno, Czech Republic } \\ \text { Curator } & \text { Jan Novák - Hana Zezulová } \\ \text { Organiser } & \text { MZM } \\ \text { Note } & \begin{array}{l}270 \text { items. The exhibition presented the work of the excellent sculptor, carver, restorer and } \\ \text { puppeteer Vojtěch Sucharda, displaying some of his sculptures: plastic art and architectonic } \\ \text { decorations, exteriors and interiors. The core of the exhibition was Sucharda’s work for the Ř́še } \\ \text { loutek Theatre that he co-founded with his wife Anna Suchardová-Brichová in } 1920 \text { and led } \\ \text { artistically for } 36 \text { years. }\end{array}\end{array}$

\section{Divadlo českých potulných loutkářu (Theatre of Czech Itinerant Puppeteers)}

$\begin{array}{ll}\text { Dates } & \text { 28.2.2013-1.9.2013 } \\ \text { Venue } & \text { Muzeum Východních Čech (East Bohemian Museum), } \\ & \text { Hradec Králové, Czech Republic } \\ \text { Curator } & \text { Jaroslav Blecha } \\ \text { Organiser } & \text { MZM } \\ \text { Co-Organiser } & \text { Muzeum Východních Čech } \\ \text { Note } & 96 \text { items. The exhibition presented authentic artefacts from the MZM's collections outlining } \\ & \text { the historical form of Czech marionette theatre and its social status and function, highlighting } \\ & \text { its visual styles and the most common technologies of puppets and decorations. Select work of } \\ & \text { leading carvers of the } 19^{\text {th }} \text { and early } 20^{\text {th }} \text { centuries were displayed, presenting different puppet } \\ \text { styles, character types and the carving styles of their makers. }\end{array}$

\section{Skromné stánky múz (Modest Little Temples of the Muses)}

$\begin{array}{ll}\text { Dates } & \text { 6.6.2013-1.9.2013 } \\ \text { Venue } & \text { Severočeské muzeum (North Bohemian Museum), Liberec, Czech Republic } \\ \text { Curator } & \text { Jaroslav Blecha } \\ \text { Organiser } & \text { MZM } \\ \text { Co-Organiser } & \text { Festival Mateřinka, Naivní divadlo Liberec } \\ \text { Note } & \begin{array}{l}120 \text { items. The exhibition presented the phenomenon of the family puppet theatre of the early } \\ 20^{\text {th }} \text { century on authentic artefacts from MZM's collections - a selection of the most attractive } \\ \text { and visually valuable artefacts, such as industrially produced table-top puppet theatres, pup- } \\ \text { pets, printed stage decorations, properties. }\end{array}\end{array}$

\section{Herectvo na drátech (Thespians on Wires)}

$\begin{array}{ll}\text { Dates } & \text { 18.5.2014-28.10.2014 } \\ \text { Venue } & \text { Humprecht Castle, Sobotka, Czech Republic } \\ \text { Curator } & \text { Jaroslav Blecha } \\ \text { Organiser } & \text { MZM } \\ \text { Co-Organiser } & \text { Sobotka Town Council, Humprecht Castle }\end{array}$


Martina Pecková Černá

List of Puppetry Exhibitions by Czech Organisers in the Czech Republic and Abroad 1989-2015

\section{Chrudim Puppet Museum (MLK); Muzeum loutkářských kultur, Chrudim}

\section{Czech Marionettes from the Traditional to the Modern}

$\begin{array}{ll}\text { Dates } & \text { 1.4.1990-1.7.1990 } \\ \text { Venue } & \text { Radebeul, GDR } \\ \text { Organiser } & \text { MLK }\end{array}$

\section{Czech Marionettes from the Traditional to the Modern}

$\begin{array}{ll}\text { Dates } & 29.9 .1990-29.10 .1990 \\ \text { Venue } & \text { Wałbrzych, Poland } \\ \text { Organiser } & \text { MLK }\end{array}$

\section{Historický vývoj bábkového divadla (A Historical Development of Puppet Theatre)}

$\begin{array}{ll}\text { Dates } & 1.4 .1992-30.6 .1992 \\ \text { Venue } & \text { Podtatranské muzeum (Tatra Museum), Poprad, Czechoslovakia } \\ \text { Organiser } & \text { MLK }\end{array}$

$$
\begin{aligned}
& \text { České loutkové divadlo - historie a současnost } \\
& \text { (Czech Puppet Theatre - History and the Present) }
\end{aligned}
$$

Dates $\quad 11.9 .1992-15.11 .1992$

Venue Hornonitranské muzeum (Upper Nitra Museum), Prievidza, Slovakia

Organiser MLK

Note In 1993 and 1994, the exhibition toured other Slovak cities and towns (Topolčiany, Levice, Nová Baňa, Trenčín; in 1994, Modrý Kameň).

\section{Zahraniční loutky ze sbírek Muzea loutkářských kultur v Chrudimi \\ (Foreign Puppets from the MLK Collections)}

$\begin{array}{ll}\text { Dates } & \text { 15.11.1993-10.1.1994 } \\ \text { Venue } & \text { Hornonitranské muzeum (Upper Nitra Museum), Prievidza, Slovakia } \\ \text { Curator } & \text { Petr Tomášek } \\ \text { Organiser } & \text { MLK } \\ \text { Note } & \begin{array}{l}\text { Examples of puppets from all continents. In 1994, the exhibition toured other Slovak cities and } \\ \text { towns (Topolčiany, Levice, Nová Baňa). }\end{array}\end{array}$


(Czech Puppet Theatre - History and the Present)

$\begin{array}{ll}\text { Dates } & \text { 7.11.1994-4.12.1994 } \\ \text { Venue } & \text { Teatr Dzieci Zagłębia, Będzin, Poland } \\ \text { Curator } & \text { Petr Tomášek } \\ \text { Organiser } & \text { MLK }\end{array}$

\section{(Czech Puppet Theatre - History and the Present)}

$\begin{array}{ll}\text { Dates } & \text { 5.12.1994-5.1.1995 } \\ \text { Venue } & \text { Czech Centre, Warsaw, Poland } \\ \text { Curator } & \text { Petr Tomášek } \\ \text { Organiser } & \text { MLK }\end{array}$

\section{České rodinné loutkové divadlo (Czech Family Puppet Theatre)}

Dates 28.7.1995-10.9.1995

Venue Západoslovenské muzeum (West Slovak Museum), Trnava, Slovakia

Curator Petr Tomášek

Organiser MLK

Note In 1995 and 1996, the exhibition toured other Slovak cities and towns (Prievidza, Topolčiany, Nová Baňa, Levice, Galanta, Topoľčianky, Bratislava).

\section{Historic Marionettes Exhibition from the Chrudim Puppet Museum Collections}

$\begin{array}{ll}\text { Dates } & \text { 5.9.1996-2.2.1997 } \\ \text { Venue } & \text { Fondation Neumann Gingins, Switzerland } \\ \text { Organiser } & \text { MLK } \\ \text { Co-Organiser } & \text { Fondation Neumann }\end{array}$

Marionettes Exhibition from the Chrudim Puppet Museum Collections

$\begin{array}{ll}\text { Dates } & \text { 10.10.1996-28.10.1996 } \\ \text { Venue } & \text { Loeb Shopping Centre, Bern, Switzerland } \\ \text { Organiser } & \text { MLK }\end{array}$

\section{Czech Family Theatre}

$\begin{array}{ll}\text { Dates } & \text { 10.12.1996-30.1.1997 } \\ \text { Venue } & \text { Czech Centre, Warsaw, Poland } \\ \text { Curator } & \text { Petr Tomášek } \\ \text { Organiser } & \text { MLK }\end{array}$


Martina Pecková Černá

List of Puppetry Exhibitions by Czech Organisers in the Czech Republic and Abroad 1989-2015

Czech Puppet Theatre - History and the Present

Dates 20.4.1997-28.4.1997

Venue Doetinchen, Netherlands

Curator Petr Tomášek

Organiser MLK

Co-Organiser Doetinchen - Pardubice, partnership of cities

\section{České rodinné loutkové divadlo (Czech Family Puppet Theatre)}

$\begin{array}{ll}\text { Dates } & \text { 25.9.1997-24.2.1998 } \\ \text { Venue } & \text { Dusík Theatre, Čáslav, Czech Republic } \\ \text { Curator } & \text { Petr Tomášek }\end{array}$

Organiser MLK

Note Select puppets, stage decorations and theatre constructions, both original and serially produced, covering the period from the late $19^{\text {th }}$ century. The exhibition toured other Czech cities and towns: Strážnice (1998), Březnice (1999), Uherský Brod (2000), Brno (2001), Třinec (2001), Bechyně (2001), Vyškov (2002), Skuteč (2004), Hradec Králové (2004), Prostějov (2005), Strážnice (2009), Chrudim (2011)

\section{Rodinné loutkové divadlo v našich zemích (Family Puppet Theatre in Our Country)}

Dates 6.11.1997-25.1.1998

Venue $\quad$ Muzeum Těšínska (Těšín Region Museum), Český Těšín, Czech Republic

Curator Petr Tomášek

Organiser MLK

Co-Organiser Muzeum Těšínska (The Těšín Region Museum)

Note The historical part of the touring exhibition from the Chrudim Puppet Museum's collections. Family and professional puppet theatres.

České loutkové divadlo - historie a současnost

(Czech Puppet Theatre - History and the Present)

Dates

12.11.1997-7.12.1997

Venue

Městské muzeum (City Museum), Ústí nad Orlicí, Czech Republic

Curator Petr Tomášek

Organiser

MLK

Note

Traditional Czech marionettes of the folk puppeteers, examples of serially produced puppets for social theatres and of the work of contemporary professional theatres. From the Chrudim Puppet Museum's collections. The exhibition toured other Czech cities and towns: Mariánské Lázně (1998), Třebechovice pod Orebem (1998), Český Krumlov (1998), Třebíč (1999), Náchod (1999), Králíky (1999), Mladá Boleslav (1999), Sokolov (1999), Slavkov u Brna (1999), Dačice (1999), Břeclav (2000), Liberec (2001), Moravský Krumlov (2001), Zlín (2001), Náměšṫ nad Oslavou (2003), Kroměříž (2003), Př́bram (2003), Kamenice nad Lipou (2003), Humpolec (2003), Vlašim (2003), Žatec (2005), Teplice (2005), Peruc (2005), Havířov (2010) 


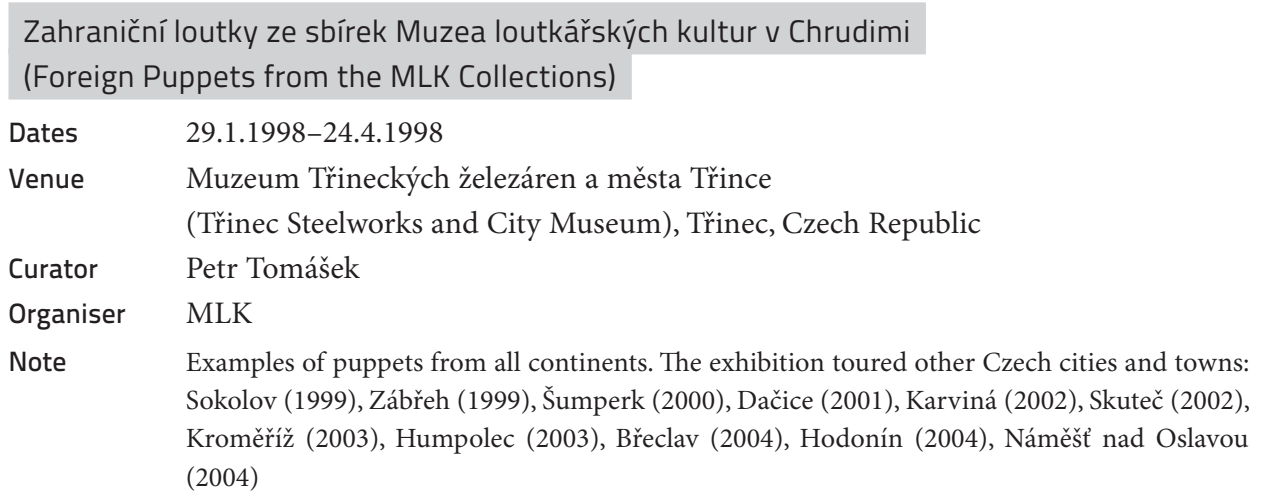

Historic Czech Puppets and Modern Puppets from the Repository of Long-Term Loans

$\begin{array}{ll}\text { Dates } & \text { 2.2.1998-23.2.1998 } \\ \text { Venue } & \text { Youth Palace, Katowice, Poland } \\ \text { Organiser } & \text { MLK }\end{array}$

Exhibition of the Chrudim Puppet Museum's New Collections

$\begin{array}{ll}\text { Dates } & \text { 27.2.1998-14.4.1998 } \\ \text { Venue } & \text { Galerie Sztuki Wspołczesnej BCK, Brzeg, Poland } \\ \text { Organiser } & \text { MLK }\end{array}$

\section{Exhibition of the Chrudim Puppet Museum's New Collections}

Dates 18.4.1998-25.4.1998

Venue Wojewódski Ośrodek Kultury, Bielsko-Biała, Poland

Organiser MLK

Historic Czech Puppets and Modern Puppets from the Repository of Long-Term Loans

$\begin{array}{ll}\text { Dates } & \text { 29.4.1998-28.6.1998 } \\ \text { Venue } & \text { Racibórz Museum, Racibórz, Poland } \\ \text { Organiser } & \text { MLK }\end{array}$
Historic Czech Puppets and a Showcase of the Work of Today's
Professional Puppet Theatres

Dates 27.8.1998-24.9.1998

Venue $\quad$ Muzeum Chemiczna 12, Sosnowiec, Poland

Organiser MLK 
Martina Pecková Černá

List of Puppetry Exhibitions by Czech Organisers in the Czech Republic and Abroad 1989-2015

Loutkové divadlo Radost - 50 let s radostí

(The Radost Puppet Theatre - 50 Years with Radost [Joy])

Dates 26.2.1999-9.1.2000

Venue $\quad$ MLK, Chrudim, Czech Republic

Organiser MLK

Co-Organiser Loutkové divadlo Radost (Radost Puppet Theatre)

Note An exhibition marking the 50 years since the establishment of the theatre.

Hračky české i zahraniční ze sbírek Muzea loutkářských kultur v Chrudimi

(Czech and Foreign Toys from the MLK Collections)

Dates 2.6.1999-29.8.1999

Venue Regional Museum, Tachov, Czech Republic

Curator Petr Tomášek

Organiser MLK

Note Select artefacts of Czech toys from history to the present. Examples from Europe, Asia and America.

Traditional Czech Puppets and Professional Theatre Puppets

Dates 24.6.1999-30.9.1999

Venue Kijk \& Luistermuseum, Bennekom, Netherlands

Organiser MLK

Tradiční české marionety a loutky z profesionálních loutkových divadel

(Traditional Czech Puppets and Professional Theatre Puppets)

Dates 14.10.1999-22.11.1999

Venue Východoslovenská galéria (East Slovak Gallery), Košice, Slovakia

Organiser MLK

Czech Puppet Theatre - History and the Present

Dates 21.5.2001-15.10.2001

Venue $\quad$ Espace marionettes Minez Cluon, Gourin, France

Curator Petr Tomášek

Organiser MLK

Narodím se znovu? (O znovuzrození českého Kašpárka)

(Shall I be born again?: On the Resurrection of the Czech Kašpárek)

$\begin{array}{ll}\text { Dates } & \text { 8.11.2001-31.3.2001 } \\ \text { Venue } & \text { Bibiana, Bratislava, Slovakia } \\ \text { Organiser } & \text { MLK }\end{array}$




\section{Czech Puppet Theatre - History and the Present}

$\begin{array}{ll}\text { Dates } & \text { 19.5.2002-10.6.2002 } \\ \text { Venue } & \text { Muzej primenjene umetnosti, Beograd, Serbia } \\ \text { Curator } & \text { Petr Tomášek } \\ \text { Organiser } & \text { MLK }\end{array}$

\section{Czech Puppet Theatre - History and the Present}

$\begin{array}{ll}\text { Dates } & \text { 28.11.2002-23.2.2 } \\ \text { Venue } & \text { Tel Aviv, Israel } \\ \text { Curator } & \text { Petr Tomášek } \\ \text { Organiser } & \text { MLK }\end{array}$

\section{Czech Puppet Theatre - History and the Present}

Dates 15.11.2003-31.1.2004

Venue Wasserschloss Klaffenbach, Chemnitz, Germany

Curator Petr Tomášek

Organiser MLK

Co-Organiser Czech Centre in Dresden, General Consulate of the Czech Republic in Dresden

\section{Lampion je divadlo (The Lantern is a Theatre)}

$\begin{array}{ll}\text { Dates } & \text { 17.1.2004-31.12.2005 } \\ \text { Venue } & \text { MLK, Chrudim, Czech Republic } \\ \text { Organiser } & \text { MLK } \\ \text { Co-Organiser } & \text { Lampion Theatre }\end{array}$

Note The puppets and stage objects for the Kladno puppet theatre (artists Alois Tománek, Zdeněk Hajdúch and others). On the $55^{\text {th }}$ anniversary of the Lampion Theatre.

Czech Puppet Theatre - History and the Present

$\begin{array}{ll}\text { Dates } & \text { 28.4.2004-13.5.2004 } \\ \text { Venue } & \text { Council of Europe, Strasbourg, France } \\ \text { Curator } & \text { Petr Tomášek } \\ \text { Organiser } & \text { MLK }\end{array}$

Czech Puppet Theatre - History and the Present

Dates 5.11.2004-3.1.2005

Venue Latvian State Puppet Theatre, Riga, Latvia

Curator Petr Tomášek

Organiser MLK 
Martina Pecková Černá

List of Puppetry Exhibitions by Czech Organisers in the Czech Republic and Abroad 1989-2015

\section{Všichni čerti světa (All the Devils of the World)}

Dates 3.12.2004-1.2.2005

Venue Divadlo rozmanitostí (Varieties Theatre), Most, Czech Republic

Organiser MLK

Note Historic and modern puppets of devils.

\section{Šašci a kašpaři pražské Říše loutek}

(The Clowns and Jesters of the Řiše loutek Theatre of Prague)

$\begin{array}{ll}\text { Dates } & \text { 15.2.2005-15.2.2006 } \\ \text { Venue } & \text { MLK, Chrudim, Czech Republic } \\ \text { Organiser } & \text { MLK }\end{array}$

Note Vojtěch Sucharda’s puppets in Anna Suchardová-Brichovás costume from the first half of the $20^{\text {th }}$ century. On the $85^{\text {th }}$ anniversary of the Říše loutek Theatre.

\section{Czech Puppet Theatre - History and the Present}

Dates 17.2.2005-30.3.2005

Venue Hevosenkenkä Theatre, Helsinki, Finland

Curator Petr Tomášek

Organiser MLK

\section{Dve storočia s českými bábkami (Two Centuries with Czech Puppets)}

$\begin{array}{ll}\text { Dates } & \text { 7.9.2006-8.10.2006 } \\ \text { Venue } & \text { Štátna galéria (State Gallery), Banská Bystrica, Slovakia } \\ \text { Organiser } & \text { MLK }\end{array}$

\section{Dvacet let rozmanitostí (Twenty Years of Variety [Puppet] Theatre)}

Dates $\quad$ 15.1.2007-30.12.2007

Venue MLK, Chrudim, Czech Republic

Organiser MLK

Note An exhibition on the history and the artists of the Varieties Theatre in Most.

\section{Friends on Strings}

$\begin{array}{ll}\text { Dates } & \text { 15.3.2007-30.9.2007 } \\ \text { Venue } & \text { Theatre Museum, Cable Factory, Helsinki, Finland } \\ \text { Organiser } & \text { MLK }\end{array}$




\section{Puppetry! Suspended Imagination}

Dates 12.4.2007-30.9.2007

Venue $\quad$ National Czech \& Slovak Museum \& Library, Cedar Rapids, USA

Organiser MLK

\section{Loutky k českým lidovým pohádkám (Puppets for Czech Folk Tales)}

$\begin{array}{ll}\text { Dates } & 31.5 .2007-9.6 .2007 \\ \text { Venue } & \text { Festival Meteorit, Kolárovo, Slovakia } \\ \text { Organiser } & \text { MLK }\end{array}$

\section{Drak 50 let (50 Years of the DRAK Theatre)}

Dates 24.1.2008-30.12.2008

Venue $\quad$ Mydlářský dům (The Mydlář House), Chrudim, Czech Republic

Organiser MLK

Note Puppets and scenography of the Drak Theatre in Hradec Králové. On the $50^{\text {th }}$ anniversary of the company.

\section{Czech Puppets}

$\begin{array}{ll}\text { Dates } & \text { 13.6.2008-13.9.2008 } \\ \text { Venue } & \text { Kijk \& Luistermuseum, Bennekom, Netherlands } \\ \text { Curator } & \text { Petr Tomášek } \\ \text { Organiser } & \text { MLK }\end{array}$

\section{Friends on Strings}

$\begin{array}{ll}\text { Dates } & \text { 31.7.2008-13.9.2008 } \\ \text { Venue } & \text { Museum Kymenlaakson Hämeenlinna, Finland } \\ \text { Organiser } & \text { MLK }\end{array}$

Verwurzeltes (Rooted)

$\begin{array}{ll}\text { Dates } & 6.10 .2008-17.4 .2009 \\ \text { Venue } & \text { Mistelbach, Austria } \\ \text { Organiser } & \text { MLK }\end{array}$

\section{Friends on Strings}

$\begin{array}{ll}\text { Dates } & 30.10 .2008-15.2 .2009 \\ \text { Venue } & \text { Kotka, Finland } \\ \text { Organiser } & \text { MLK }\end{array}$


Martina Pecková Černá

List of Puppetry Exhibitions by Czech Organisers in the Czech Republic and Abroad 1989-2015

\section{Stínové divadlo (Shadow Theatre)}

Dates 22.1.2009-30.12.2009

Venue $\quad$ MLK, Chrudim, Czech Republic

Organiser MLK

Note $\quad$ Puppets of India, Indonesia and China.

Naivní divadlo Liberec ve sbírkách Muzea loutkářských kultur v Chrudimi

(The Naïve Theatre Liberec in the MLK Collections)

Dates 22.1.2009-30.12.2009

Venue $\quad$ MLK, Chrudim, Czech Republic

Organiser MLK

Co-Organiser Naivní divadlo (Naïve Theatre)

Note On the $60^{\text {th }}$ anniversary of the Naïve Theatre Liberec

\section{UNIMA 2009}

$\begin{array}{ll}\text { Dates } & \text { 7.5.2009-30.8.2009 } \\ \text { Venue } & \text { MLK, Chrudim, Czech Republic } \\ \text { Organiser } & \text { MLK } \\ \text { Note } & \text { An exhibition to mark the } 80^{\text {th }} \text { anniversary of the international puppetry organisation, } \\ & \text { presenting its past and present. }\end{array}$

Od Ústředního loutkového divadla k Minoru

(From the Central Puppet Theatre to the Minor)

Dates 3.3.2010-31.12.2011

Venue $\quad$ MLK, Chrudim, Czech Republic

Organiser MLK

Co-Organiser Minor Theatre

Note The exhibition maps the 60 years' history of the Prague-based puppet theatre.

Biennale of Illustrations Bratislava XXII: Traveling Exhibition in Japan

Dates 17.4.2010-29.8.2010

Venue Hiratsuka Museum, Japan

Organiser MLK

Note 216 exhibited items from the collections of MLK. 


\section{0 let s Přeletem (20 Years with the One Flew Over the Puppeteer's Nest Festival)}

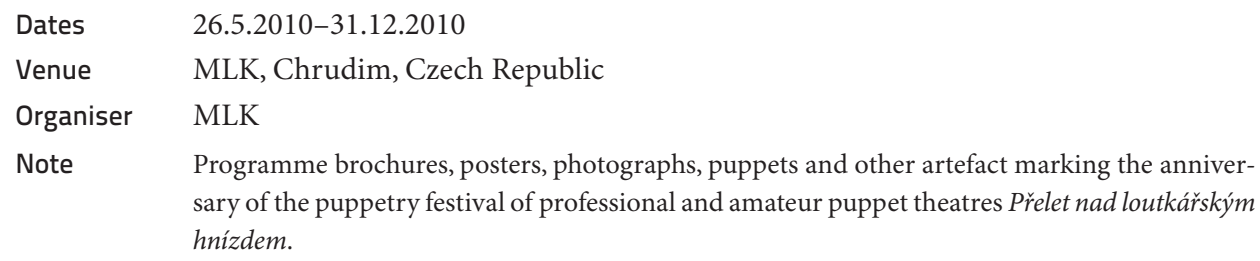

Biennale of Illustrations Bratislava XXII: Traveling Exhibition in Japan

$\begin{array}{ll}\text { Dates } & 5.10 .2010-5.12 .2010 \\ \text { Venue } & \text { Chiba City Museum, Japan } \\ \text { Organiser } & \text { MLK } \\ \text { Note } & 216 \text { exhibited items from the collections of MLK. }\end{array}$

Biennale of Illustrations Bratislava XXII: Traveling Exhibition in Japan

$\begin{array}{ll}\text { Dates } & \text { 12.3.2011-17.4.2011 } \\ \text { Venue } & \text { Ida City Museum, Japan } \\ \text { Organiser } & \text { MLK } \\ \text { Note } & 216 \text { exhibited items from the collections of MLK. }\end{array}$

Biennale of Illustrations Bratislava XXII: Traveling Exhibition in Japan

$\begin{array}{ll}\text { Dates } & \text { 23.4.2011-26.6.2011 } \\ \text { Venue } & \text { Ashikaga Museum of Art, Japan } \\ \text { Organiser } & \text { MLK } \\ \text { Note } & 216 \text { exhibited items from the collections of MLK. }\end{array}$

Biennale of Illustrations Bratislava XXII: Traveling Exhibition in Japan

$\begin{array}{ll}\text { Dates } & 9.7 .2011-31.8 .2011 \\ \text { Venue } & \text { Urawa Art Museum, Japan } \\ \text { Organiser } & \text { MLK } \\ \text { Note } & 216 \text { exhibited items from the collections of MLK. }\end{array}$

\section{Barokní loutka? (A Baroque Puppet?)}

Dates $\quad 8.12 .2011-8.1 .2012$

Venue MLK, Chrudim, Czech Republic

Organiser MLK

Note An exhibition of Baroque puppets on the frontiers of the discipline (e.g. from church rites and processions etc.). 
Martina Pecková Černá

List of Puppetry Exhibitions by Czech Organisers in the Czech Republic and Abroad 1989-2015

Kašpárci celého světa (Kašpárek Clowns of the Whole World)

Dates 19.12.2012-21.7.2013

Venue $\quad$ MLK, Chrudim, Czech Republic

Organiser MLK

Note $\quad$ Examples from Europe, Asia and America.

Loutky na frontě (Puppets on the Front)

Dates 27.7.2014-11.1.2015

Venue $\quad$ MLK, Chrudim, Czech Republic

Organiser MLK

Note An exhibition marking the centenary of the start of WWI

\section{Divadlo zrozené z vody (Theatre Born out of Water)}

$\begin{array}{ll}\text { Dates } & \text { 14.11.2014-27.9.2015 } \\ \text { Venue } & \text { MLK, Chrudim, Czech Republic } \\ \text { Organiser } & \text { MLK }\end{array}$

Note An exhibition of an authentic water puppet theatre of Vietnam. The MLK acquired the artefacts during a research trip to Hanoi and the environs of the Red River delta.

\section{Matěj Kopecký/Patron českého loutkářství (Matěj Kopecky: Patron of Czech Puppetry)}

$\begin{array}{ll}\text { Dates } & \text { 21.2.2015-21.3.2015 } \\ \text { Venue } & \text { MLK, Chrudim, Czech Republic } \\ \text { Organiser } & \text { MLK }\end{array}$

Note An exhibition dedicated to the memory of the famous Czech marionettist and his followers on the $240^{\text {th }}$ anniversary of Matěj Kopeckýs birth.

\section{Říše loutek - 95 let bez přestávky (The Řiše loutek Theatre - 95 Years Nonstop)}

Dates 13.3.2015-10.1.2016

Venue $\quad$ MLK, Chrudim, Czech Republic

Organiser MLK

Co-Organiser Ǩ́še loutek Theatre

Note A retrospective exhibition documenting the story of one of the best-known Czech puppet theatres. 


\title{
Institut umění - Divadelní ústav (ATI), Praha
}

\section{Loutky po roce nula - České loutkářství mezi tradicí a postmodernou \\ (Puppets After Year Zero - Czech Puppetry between Tradition and the Postmodern)}

\author{
Dates $\quad$ 1.7.2010-8.7.2010 \\ Venue $\quad$ Karel Pippich Theatre, Chrudim, Czech Republic \\ Curator Kateřina Lešková Dolenská \\ Organiser ATI \\ Co-Organiser Chrudim Puppet Festival \\ Note A collection of 40 photographs by different authors documenting the changes in the world of \\ puppet theatre since the fall of the Iron Curtain.
}

Irena Marečková - Za maskou loutky (Irena Marečková - Behind the Puppet's Mask)

$\begin{array}{ll}\text { Dates } & \text { 7.3.2011-8.4.2011 } \\ \text { Venue } & \text { Café Galerie Černá labut, Praha, Czech Republic } \\ \text { Curator } & \text { Helena Albertová } \\ \text { Organiser } & \text { ATI } \\ \text { Note } & \begin{array}{l}\text { An exhibition of Irena Marečkovás designs for puppets, stage sets and costumes as part of } \\ \text { a cycle of } 8 \text { exhibitions called 'Pod kř́dly Černé labutě' (Under the Wings of the Black Swan). }\end{array}\end{array}$

\section{Puppets Since Year Zero}

Dates 16.9.2011-25.9.2011

Venue Town Hall and shop windows, Charleville-Mézières, France

Curator Nina Malíková

Organiser ATI

Co-Organiser Festival Mondial des Théâtres de Marionettes

Note An exhibition of $c a .150$ puppets focusing on the work of theatre companies since 1989, covering both professional and independent theatre groups.

The Tradition and the Present of the Czech Puppet

$\begin{array}{ll}\text { Dates } & \text { 15.9.2014-26.10.2014 } \\ \text { Venue } & \text { Sofia Art Gallery, Sofia, Bulgaria } \\ \text { Curator } & \text { Nina Malíková } \\ \text { Organiser } & \text { ATI } \\ \text { Co-Organiser } & \text { Czech Centre In Sofia, Puppet Fair Sofia Festival }\end{array}$

Note $\quad 55$ items. Stage designs, puppets, masks and other artefacts of Czech puppet theatre from the oldest times to the present. 
Martina Pecková Černá

List of Puppetry Exhibitions by Czech Organisers in the Czech Republic and Abroad 1989-2015

\section{Strings Attached: The Living Tradition of Czech Puppetry}

Dates $\quad$ 8.3.2013-8.8.2013

Venue Columbus Museum of Art, Columbus, USA

Curator Nina Malíková - Joseph Brandesky

Organiser ATI

Co-Organiser Columbus Museum of Art

Note An exhibition of ca.140 puppets, artistic objects, stage designs and scenographic elements including models of black theatre. The exhibition maps the history of Czech puppet theatre from the late $19^{\text {th }}$ century to the present. See Joseph Brandesky's article in this volume.

\section{Private Puppet Collections and Collections of Puppet Theatres}

\section{Klasické české marionety ze sbírky Jiřiho Vorla \\ (Classical Czech Marionettes from Jiři Vorel's Collections)}

Dates 1991

Venue Karolinum, Praha, Czechoslovakia

Curator Jiří Vorel

Organiser Národní divadlo marionet Praha (National Marionette Theatre Prague)

\section{Zahraniční loutky ze sbírky Milana Knížáka}

(Foreign Puppets from Milan Knižák's Collections)

Dates 20.3.1998-31.12.1998

Venue $\quad$ MLK, Chrudim, Czech Republic

Curator Milan Knížák

Organiser Milan Knížák

Co-Organiser MLK

Note Examples of European and especially Asian puppets. 


\section{Muzeum loutek Milana Knížáka (Milan Knižák's Puppet Museum)}

Dates 6.12.1998-31.12.2002

Venue Děčín Castle, former Thunovský Armoury, Děčín, Czech Republic

Curator Milan Knížák

Organiser Milan Knížák

Co-Organiser Regional Council of Okresní úřad Děčín (Regional Council of Děčín)

Note A standing exhibition of Czech historic puppets of the late $19^{\text {th }}$ century from Milan Kníźák's private collection.

\section{House Full of Puppets}

Dates 6.3.1999-21.3.1999

Venue Basement of Tourism Activities Centre, Macau, Macau

Curator Marie Jirásková - Pavel Jirásek

Organiser Marie and Pavel Jirásek

Co-Organiser Macau City Fringe Festival

Note An exhibition of ca.200 historic puppets, ca.30 planary artefacts: Czech puppet scenography 1850-1950 from Marie and Pavel Jirásek's collection, documenting travelling folk marionette theatre, family puppet theatres and social club puppet theatres.

\section{Les marionettes historiques du théâtre de Prague}

Dates 15.9.2000-24.9.2000

Venue Le Musée de l'Ardenne, Charleville-Mézières, France

Curator Jan Dvořák

Organiser Národní divadlo marionet Praha (National Marionette Theatre Prague)

Co-Organiser Festival Mondial des Théâtres de Marionettes

Note A set of 70 historic marionettes of the $18^{\text {th }}$ and especially $19^{\text {th }}$ centuries, and modern puppets from the workshops of the National Marionette Theatre (productions of Don Giovanni, Orfeo ed Euridice and others).

\section{České marionety (Czech Marionettes)}

Dates $\quad 4.5 .2001-28.10 .2001$

Venue $\quad$ Egon Schiele Art Centrum, Český Krumlov, Czech Republic

Curator Jan Dvořák

Organiser Národní divadlo marionet Praha (National Marionette Theatre Prague)

Note Historic marionettes from the private collection of the Mozart Open Festival, the so-called Mikoláš Aleš theatre. 
Martina Pecková Černá

List of Puppetry Exhibitions by Czech Organisers in the Czech Republic and Abroad 1989-2015

\section{Čerti českých loutkářů a řezbářů (The Devils of Czech Puppeteers and Woodcarvers)}

$\begin{array}{ll}\text { Dates } & 1.3 .2002-1.2 .2003 \\ \text { Venue } & \text { MLK, Chrudim, Czech Republic } \\ \text { Curator } & \text { Jiří Vorel } \\ \text { Organiser } & \text { Jiří Vorel and MLK } \\ \text { Note } & \text { Puppets from Jiří Vorel's collection used in the Traditional Puppet Theatre Zvoneček of Prague. }\end{array}$

\section{Muzeum marionet (Marionette Museum)}

Dates 18.4.2002-present

Venue former St. Jošt Church, Český Krumlov, Czech Republic

Curator Jan Dvořák

Organiser Národní divadlo marionet Praha (National Marionette Theatre Prague)

Co-Organiser Divadelní centrum Český Krumlov o.s. (Theatre Centre Český Krumlov)

Note A standing exhibition containing puppets, puppet theatres and the installation of the production set of the puppet opera Orfeo ed Euridice of the National Marionette Theatre.

\section{The Naïve Theatre Liberec, Czech Republic - Puppets, Posters, Photographies}

Dates $\quad 1.12 .2006-10.12 .2006$

Venue $\quad$ Centro Municipal de las Artes, Alicante, Spain

Curator Stanislav Doubrava - Angel Casado

Organiser Naivní divadlo (Naïve Theatre)

Co-Organiser Alicante 19' - Festival internacional de títeres.

Note $\quad 50$ puppets from the productions of the Naïve Theatre.

\section{Vánoce s loutkami (A Christmas with Puppets)}

Dates $\quad 3.12 .2008-28.12 .2008$

Venue Letohrádek Mitrovských (The Mitrovských Summer Pavillion), Brno, Czech Republic

Curator Marie Jirásková - Pavel Jirásek

Organiser Marie and Pavel Jirásek

Note Historic puppet theatres, puppets and toys from the collections of Marie (designer) and Pavel (director, documentarist) Jirásek.

\section{Loutky na zámku (Puppets at a Castle)}

Dates 1.6.2009-30.6.2009

Venue $\quad$ Lysice State Castle, Lysice u Boskovic, Czech Republic

Curator Marie Jirásková - Pavel Jirásek

Organiser Marie and Pavel Jirásek

Note An exhibition of puppets and family puppet theatre from the collections of Marie and Pavel Jirásek. The exhibition continued in variants in 2010 and 2011. 
Od Kašpara k čertu (From Kašpar to the Devil)

Dates 4.11.2009-24.1.2010

Venue Masaryk Museum, Hodonín, Czech Republic

Curator Marie Jirásková - Pavel Jirásek

Organiser Marie and Pavel Jirásek

Note Puppets and complete puppet theatres intended for homes, schools and social clubs mostly from the 1920s and 1930s. The artefacts are from Marie and Pavel Jirásek's collection.

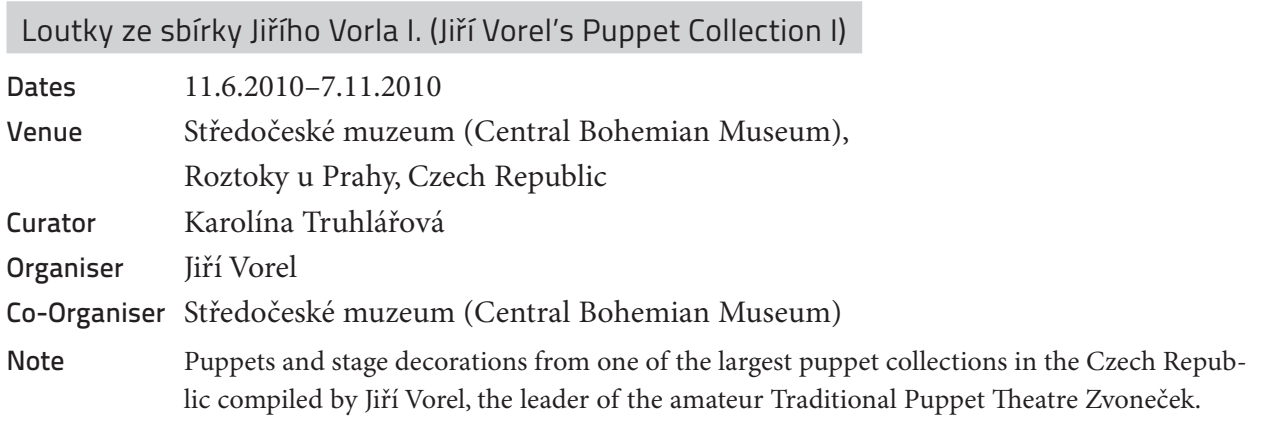

Loutky ze sbírky Jiřího Vorla II. (Jiří Vorel's Puppet Collection II)

$\begin{array}{ll}\text { Dates } & \text { 16.7.2010-21.11.2010 } \\ \text { Venue } & \text { Středočeské muzeum (Central Bohemian Museum), } \\ & \text { Roztoky u Prahy, Czech Republic } \\ \text { Curator } & \text { Karolína Truhlářová } \\ \text { Organiser } & \text { Jiří Vorel } \\ \text { Co-Organiser } & \text { Středočeské muzeum (Central Bohemian Museum) } \\ \text { Note } & \text { A continuation of the exhibition Loutky ze sbírky Jiř́ho Vorla I. }\end{array}$

The Naïve Theatre Liberec, Czech Republic - Puppets, Posters, Photographies

Dates 19.7.2010-25.7.2010

Venue Israeli Centre for Puppetry, Holon, Israel

Curator Stanislav Doubrava - Miri Piri

Organiser Naivní divadlo (Naïve Theatre)

Co-Organiser Israeli Centre for Puppetry

Note 65 puppets from the productions of the Naïve Theatre. 
Martina Pecková Černá

List of Puppetry Exhibitions by Czech Organisers in the Czech Republic and Abroad 1989-2015

\section{Česká loutka - tradice a současnost (Czech Puppet - Tradition and Present)}

Dates 30.11.2011-28.1.2012

Venue $\quad$ Galerie Smečky, Praha, Czech Republic

Curator Karolína Truhlářová

Organiser Jiří Vorel

Co-Organiser Galerie Smečky

Note Puppets, stage decorations and entire puppet theatres from the $19^{\text {th }}$ century from the workshops of contemporary woodcarvers, mostly from Jiří Vorel's collections.

Klauni, čerti, Kašpaři... (Clowns, Devils, Kašpars...)

Dates $\quad 1.12 .2011-26.2 .2012$

Venue Regional Museum Karlovy Vary, Karlovy Vary, Czech Republic

Curator Marie Jirásková - Pavel Jirásek

Organiser Marie and Pavel Jirásek

Note An exhibition of historic puppets and theatres from the end of the $19^{\text {th }}$ century to 1950 . The artefacts are from Marie and Pavel Jirásek's collection.

Grafické listy věnované časopisu Loutkář

(Graphic Sheets Dedicated to the Loutkář Journal)

Dates 21.6.2012-21.6.2012

Venue Muzeum loutek Plzeň (Puppet Museum in Pilsen), Plzeň, Czech Republic

Curator Nina Malíková

Organiser Festival Skupova Plzeň (Skupa’s Pilsen Festival)

Note A small exhibition as part of a seminar marking the $100^{\text {th }}$ anniversary of Czech puppetry publications.

\section{Úchvatný svět historických loutek (The Amazing World of Historic Puppets)}

Dates $\quad 1.5 .2013-31.8 .2013$

Venue Lešná Chateau, Valašské Meziřričí, Czech Republic

Curator Marie Jirásková - Pavel Jirásek

Organiser Marie and Pavel Jirásek

Co-Organiser Muzeum regionu Valašsko Vsetín (The Valašsko Region Museum in Vsetín)

Note An exhibition of historic puppets and theatres from 1850 to 1950. The artefacts are from Marie and Pavel Jirásek's collection. 


\section{Loutky a loutková divadla v salonu (Puppets and Puppet Theatres in the Parlour)}

Dates 1.5.2014-30.9.2014

Venue Jánský Vrch Castle, Javorník, Czech Republic

Curator Marie Jirásková - Pavel Jirásek

Organiser Marie and Pavel Jirásek

Note Puppets and complete puppet theatres intended for aristocratic families, homes, schools and social clubs from 1850 to 1950. The artefacts are from Marie and Pavel Jirásek's collection.

\section{Kouzlo rodinného loutkového divadla (The Charm of the Family Puppet Theatre)}

Dates 25.11.2014-29.3.2015

Venue Jeseník Water Fortress, Jeseník, Czech Republic

Curator Marie Jirásková - Pavel Jirásek

Organiser Marie and Pavel Jirásek

Co-Organiser Vlastivědné muzeum Jesenicka Jeseník (Ethnographic Museum of the Jeseník Region)

Note An exhibition of the puppets and family toy theatres mostly from the early $20^{\text {th }}$ century. The artefacts are from Marie and Pavel Jirásek's collection.

\section{Kouzelný svět loutkových divadel (The Magical World of Puppet Theatres)}

Dates 22.5.2015-28.9.2015

Venue Chropyně Castle, Chropyně, Czech Republic

Curator Marie Jirásková - Pavel Jirásek

Organiser Marie and Pavel Jirásek

Co-Organiser Muzeum Kroměřížska Kroměříž (The Kroměřiž Region Museum)

Note Historic puppets and theatres from Marie and Pavel Jirásek's collection. 
